\title{
A BUDAPESTI BATTHYÁNY TÉR BATTHYÁNY-SZOBRÁRÓL ${ }^{1}$ THE STATUE OF BATTHYÁNY IN BUDAPEST ${ }^{1}$
}

SZERZÖ/BY:

HTIPS://DOI.ORG/

$10.36249 / 52.3$

\section{ELÖLJÁRÓBAN}

A városok legfontosabb részei a közterületek: terek, utcák, parkok. Ezek biztosítják az egyes ingatlanok megközelitését, a kozzlekedeest, az emberek
találkozását, közös cselekvéseit (ünn peit, társadalmi megmozdulásait) és a regenerálódást (ebben kiemelkedős re van a parkoknak, kerteknek, terenek, vízp a tokn). Szeremik azonnen, ban még én haz

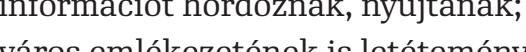
sei - hiszen az épületek cserélóndhetnek a funkciók változhatnak de az ,ak, a tón, torek Jelentö, tein Antal sorai: „Én a várossal akarom Önt megismertetni, azt hiszem a hór megión lényze a hazak az igazan lenyegesek. De talan nem is a hazak: az utcák egymasra hajlo erotikaja, melyben neha ero fejezódil ki es olykor gracia, .... "Mi a jo város? - teszi fel a kérdést Illyés Gyula Svédországban járva. O ezt a választ találta erre: „Ahol az utcán is oly otthonias vagyok, mint a lakasomban.... Azt hittem, farsangi és egyéb utca felvonulásaik, örömünnepeik azért van csak a dell népeknek, mert azok amúgy is az utcán élnek. Nem; nem az éghaj lat az elöfeltétel, hanem az otthoniasság, az együttelésnek ez a családiassága." A közterületek közül is kiemelkednek a terek: tágasságuk, helyzetük megállásra késztetik az embert s maradásra - ha alkalmasak arra ${ }^{4}$ Egyes terek különös jelentőségre tesznek szert. Pesten a Hősök tere az egész nemzet számár szimbolikus jelentőséggel bír: szent hely". Ugyanígy kiemelkedó jelenttosegel bírnak a városok föterei, a templomok, a városházák és más, jelentős középületek előtti terek, a piacterek, Egyes vá pl. Sienábs a Pizzza del Canpo, lórer chen piazzol Azza de śs ár a lás Azzerver resze a mún évsź́z ezzzuik legfonto abb megrendelő és tár tarsalonszervezo ereje is oriási vol, az enberk a logjobb nuszek akotásain nevelkedtek, izlescuk e múveken csiszolódott - fejti ki Borsos Miklós egy irasában. ${ }^{5}$ S hozzáteszi: A reneszánsztól, skivaltképp a barokktól ez alapvetoen megvaltozott. Megitelesem szerint ma a köztéri mủalkotások, elsősorban a szobrok azok, amelyekhez mindenki egyará „hozzáererhet, belépó és engedély nélkül szemlélhetők, ízlésünket - kultúrán-
1 Szobrász: Stremeny Géza, tajépitész: es Ivánui c Kofaragók: Fáskerti Istuán

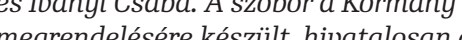
Batthyánn-emlékéevre (születésésenek 200 eves fordullojaraa), zoof-re készuilt volna
el, de véguil 2008. aprilis 15 -en került so az avatósra.

2 Szerb Antal: Budapesti Kalauz Marslakok számára. Magvetö Kft. Bp. zoo5. EreNyomtatta: Löblossary Sandor rajzaiva, 3 Illyés Gyula: Útirajzok - Suéd fö̈ldön. Útirajzok, esszék, tanulmányok, Szépir dalmi Könyvikiadó, Budapest, 1982. Kiadó, Bp. 2014 5 A gondolat Borsos Miklós: A toronybol

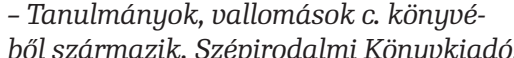
Budapest, 1979 . kat alakítják. Ez nagy felelösséget ró az alkotókra és a megrendelōkre egyaránt. Egy-egy példán még jobban megérth jük, hogy egy tér és egy-egy szobor mit üzenhet nekünk. $\mathrm{S}$ azt is, hogy milyen felelősség egy köztéri szobrot állítani.

A TÉRRŐL

A térnek, amelynek Buda töröktől való visszafoglalása óta igen változatos a használata, gazdag a története (a cśszári hadsereg állomáshelye, raktárbázisa, piactér a Felső-Víziváros lakói részére, rajta kicsi kápolna; majd köztér és tömegközlekedési csomópont), körülötte történelmi épületek, mủemlékek sora a barokktól a XIX. század végéig. ${ }^{6}$ Magának a térnek a történ is jól példázza, hogy milyen jelentösége van egy város számára a térnek. török hódoltság elótti időkben a ferences kolostor kertje terül el itt: ennek alapjann igenyelte vissza a rend a területet Buda visszafoglalását (1686) követóen.' A téren a császári csapatok hadfelszerelés-raktára allt sokáig - ezért volt a Bomba tér elnevezés. A hely stratégiai szenpontból kiváló, mivel a Dun ive miatt mind eszak, mind dél felé hos szan belátható a folyó. ${ }^{8}$ Végül a város szerezte meg a területet, s vásárokat rendeztek rajta (Felső-vásártér), majd káponát épitettek (hogy a letelepült katonákat lelkileg „neveljék”, szelídítsék). A teret 1939-től Kölcsey szobra dísz tette. A szobor eredetileg Nagykároly városának megrendelésére készült, közadakozásból készült a Millenniumra. 1894-ben avatták fel ${ }^{9}$ Miután az elpusztult, készült el egy másolat, változat Budapesten ${ }^{10} \mathrm{~A}$ tér jelentős részeéppen a közze -évtizedekig felvonús terïlt volt mert 105 -tól 1972-ig a metró pítését szolǵlta. A Metró megnitás

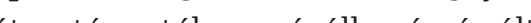
elo rzobor mentesitésére de ezek egyelóre csok részleges eredményt hoztak; egy radika is megoldás még nagyon várat magára.

\section{A SZOBORRÓL}

A mártír miniszterelnök, gróf Batthyany Lajos szobra a plébania épülete elót all, nagy vadgesztenyefák kôzôtt, félkörben kőpad veszi körül." A szálegyeneen, osszeszedetten alló karcsú férfialak egy posztamensul szolgâlo hajoorron all. Egyik kezében kiterített papírtekercset
6 Körmendy Klára: A budai Batthyány térés a Szent Anna-templom. Kézirat. tér. Képzömüvészeti Alap K. Bp. 1958.

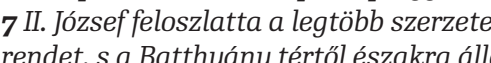
rendet, sa Batthyány terttol eszakra allo
templomot és rendházat az osztrák alapitású Erzsébet-apácáknak adta, a fere álló, korábbi Ágoston-rendi kolostorba. $\boldsymbol{8}$ A törö̌k kiüzesét követóén komoly eró 1827 és 1839 között (Bécs, a császárváros védelmében), mert tartottak az Oszmán Birodalom újbóli támadásától. vényen állt a szobor sígy nem magába roskadva ábrázolta a költö́t, hanem úg mint aki az elotte allo ember szemebe néz. Forrass: www.kozterkep.hu szobrász, Kallós Ede (1866-1950) már 73 eves volt, ezért említik, hogy a budapesti, változat" az eredetetiöntö́forma lap-
ján készült, s azon nem az idós mester végezte a végsó finomításokat.

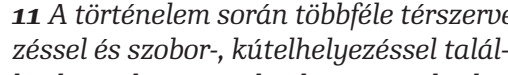
zéssel és szobor, kutelhelyezéssel talkkutak a tér szélén állnak. Ilyen például Siena fótere (egy kút áll a tér szegélyén) közopén" all L Cosimo de' Medici lovas szobra /1594/, de az igazán jelentős alkotások a tér szzéléhez közel állnak: Michelangelo Dávidja $/ 1504 /$, Donatello
Judités Holofernese $1460 /$ a Neptun ber 1575/. Giambologna Szabin nókelrablása/1534/. 
tart magasra, amelyen hitvallása, „credója" olvasható: törvény, igazság, jog. ismertetōk szerint azt ábrázolja, an kor Pozsonyból Bécsbe vitte - az uralkodóval jôvahagyatni, szentesíteni - az 1848. áprilisi törvényeket. A hihetetlenül karcsú hajótest eszünkbe juttatja azt a bizonytalan helyzetet, ami az urakodó és a magyar polgári forradalom képviselói között egyeztetni akaró politikus számára adatott, tovabbaa a hajo részleges volta (csak az orr-rész áll ott) utal arra a szerepre, ami a szabadságharc leverése után érte utol a miniszterelnököt: utolsóként sem hagyta el a "süllyedő" hajót. Illyés Gyula az Ebéd a kastélyban c. regényében leírt - a ransját elvesztett helyi gróffal folytatott - beszélgetésben, történelmi eszmecserét folytatva a magyar arisztokrácia múltjáról és mulasztásairól, kifejti, hogy azért kapták a kiváltságokat, hogy ha kell vállalják az ezzel járó következményeket is. E szerint Batthyány nem volt hös, de elmondhatjuk, hogy többek kel szemben, ő nem menekült el sorsa elöl. ${ }^{12}$ Abban bízott, hogy a jog a törvény és az igazsá útjón járva rendez-

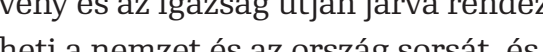
heli a älhető a fegyves konfikt, Az egyszen" szobor üzenete mé összetettebb: a hajóorrot a Batthýg

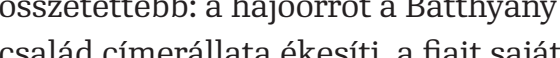
csénével tápláló pelikén A najorr diszvése ösi szońs, elég itta Kr. elótti a satzadból szarmazo szato zadohl szám Jen Jelen esetben a pelikán egészen apro, replo, hanem a rajta áló ajo a De replo, hanem a rajta allo alak. De hanyozna, ha nem lenne ott. A flait saját verével tápláló pelikán a XII. század óta jelentōs Krisztus-szimbolum is. A család címerállat-vallasztása talán erre is utal. Minden esetre a mátinhalalt halt miniszterelnök vére ontása nem volt hiábavalo: emlékeztetett es erő́t adot a függetlenségért küzdo utódoknak. A posztamens két oldalán, közel hajóorrhoz két kör alakú véset gaz- dagitja tovább a látványt és az üzenetet: egyik oldalon a családi címer, már ismert jelenettel és koorule a jelmondat: Fidelitate et Fortitudine - azaz Hüséggel és Erősséggel. A másik oldaon a miniszterelnöki pecsét rajzolata idézi fel az első felelős magya kormányt, annak vezetỏjét.

Az alak jobb keze a háta mogoött van (lazán behajlitott ujjakkal), s ez a kéztartás még jobban osszeszedetté, ünnpélyessé teszi a testtartást. Bal oldalán kard, erről és magáról a szoborról így vall az alkotó, Stremeny Géza szobrászművész: „Batthyány Lajos a törvény embere volt, mindent megtett azért, hogy közvetítsen a forradalmi nemzet és az uralkodó között. Ennek jelképeként is felfogható a hajó, amelyen áll. De a kardnak is ott a helye az oldalán, mégiscsak ő volt, aki felállitotta a honvédséget, hogy megfékezze az udvar parancsára Pest felé nyomuló Jellasics horvát bánt."

,A legnehezebb feladat az volt,

hogy a kortárs müvészet formanyelvét alkalmazó alkotás híven adja viszsza a XIX. századi höst. Ráadésul nem lehetett figyelmen kívül hagyni a köztéren a szoborral naponagyn kozó emberek ízlésvilágát sem ${ }^{214}$ Ebben a hármas elvárásrendszeben kellett megtálnni k kényes egyenślyt az alkóknak ami-ves egy nyem szerint kiválóan sikert.

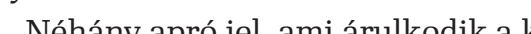

. mány stiliź́t, de a felïet rï

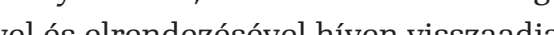
annak jellót A csizm sź́r hnak jelleget. A csizma szárának felsó le nen rajzolodik ki - egybofolyk a na rággal. Ḿn ńét elem ábrázolásának a tér mási ujoján jol tanulmányozhato a tér másik oldalăn lévô Kolcsey-szoborral osszevetve. Ma nem a kor ruházatát, viseletet akarjuk bemutatni, nem annak akarunk emleket állitani, hanem a felelósséget felvállaló, a nemzetért életét áldozó embernek. S minden apró rész let, ami lekötné figyelmünket, könnyen elterelhetné a figyelmet a lényegről.
12 Illyés Gyula: Ebéd a kastélyban, Szép13 Borso Miktos A, Budapest, 1985. nyok és vallomások, Szépirodalmi, Budapest, 1979. A könyvben csodálatos elem$\mathbf{1 4}$ www.nol.hu/archivum/

14 www.nol.hu/archivu
archiv-469336-271933
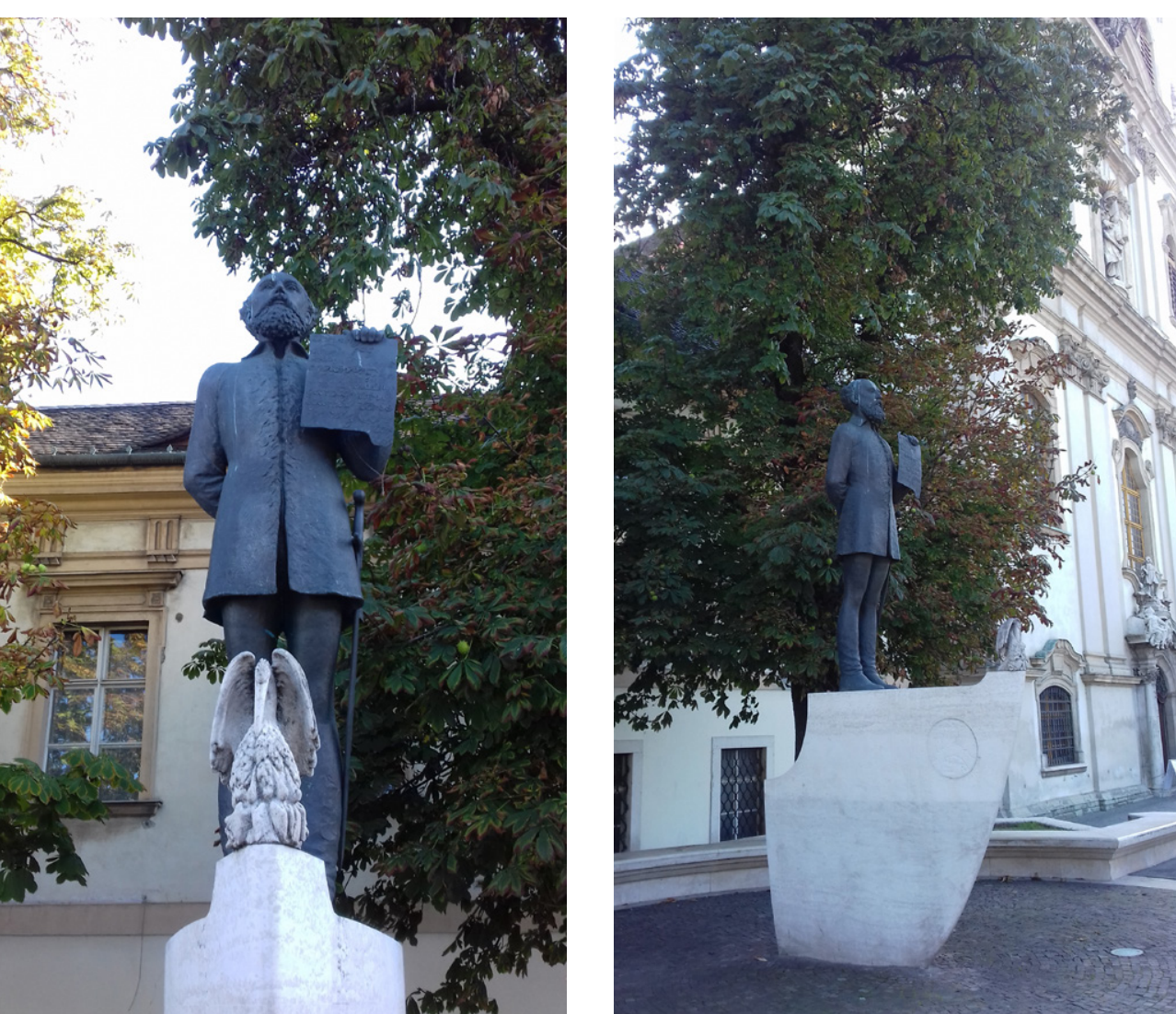

A k kepp

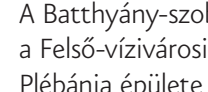

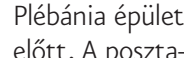
elott. A postat-
mensen a salad
cinér

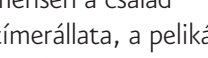

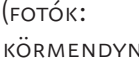
sop uniew

Az államférfi távolba tekint, szeme mintha a jövendőt fürkészé́ Első pilanatra talán meghökkentő, de szakállának rajzolata, megielenése és a fiait tápláló pelikán megý́n csörrel szaggatott tollazata hasonló. Ez (is) kapcsolatot teremt a részletgazdag bronzalak és a fontasztikus sinaśgú posztamens, azaz a hajótest között.

A SZOBOR ELHELYEZÉSE ÉS KÖRNYEZETE

A szobrot övező, annak hátteret is képező kőpad és a térburkolatban fekvô kőkör a barokk korban, a templommal egy időben is készülhetett volna (talán a tokeletes simaságú gépi csiszoláson és kofelületen kivul - amelyet nem patinásitott még az ido); egyedul a körtől kifor duló két "szárny" befejezōdése, kváz félbemaradása a „kortárs" megoldás. A szobor elhelyezese - az adott lehetôségek közot - teltalalat. Sok szobrot állítanak olyan helyre, hogy körbe-
Járható legyen. Ezt itt is meg lehet tenni, de egy embernek arca van, egy elülsố dala (ha szabad ezt a kifejezést haszhatjuk a hangját. A plébánia épülete biztos hátteret képez a szoami előtt kivégezték az Újépület mögötti fapiacon. Még jobb lehet a környezete, ha sikerül a teret részben mentesíteni a gépkocsiforgalomtól, s ezáltal az lőtte lévő térfelület kitágulhat, s a szoülő nem a várakozó taxis és a buszok lát vánában lesz kénydeźs híjén is megoldhátó len hogy taxik várakozási helyét megövidítve axzik várakozási helyét megroviditve bővïljö̈n a járda (s akkor a gépkocsik

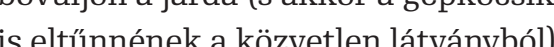
Az alkotás nem a pén látványboll. (nem létező) tengelyében áll, hanem két koros vadgesztenye között középen. A hátterben a szobrot körülölelö - majdnem fêkörnyi - kôpad ketoldalt kinyilik, majd ferdén befordulva ér véget. , s azzal szembeállva nézhetünk a bornak, s arra a palánkra, falra is utal, 


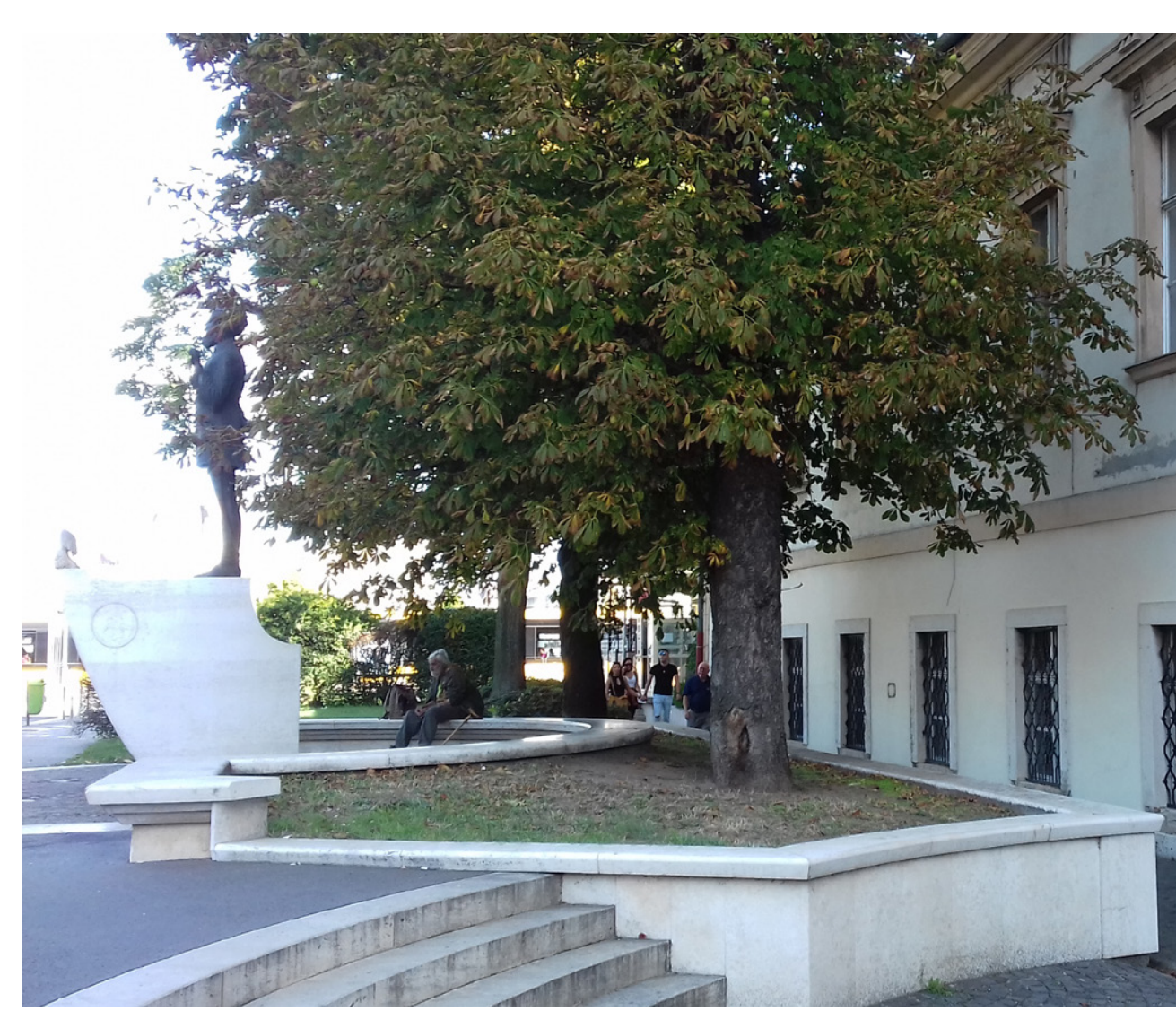

A templom felőli végen ráfordul a plébánia és a templom kapuja felé: a padot a füves térséget szegélyező kő folytatja, ami a lépcsők mellett támfallá növekszik. A lépcsó elegáns ívvel fordul a szo-
bor környezetéhez. A különböző korban épült két rész - a templom elő́t ban épült két rész - a templom elót sullyesztett térresz es az alkotás kòTörök Ṕ́ter, a szobor környezeté nek tervezője így vall az elhelyezésröl: nek tervezóje így vall az elhelyezésról: "Nagyon fontos egy szobor környezete, tómuló Szent Gellért szerzsebet hidról feekaszkód, a vizesés, a körötte és mönötte áló növónyzt. Az egyszer kor alokn allo novenyzet. Az ayszera kór alakú kon jur celom volt elualaszani-legalabb Gllomóstól A szzbr dezhetuik a prebrnia elóti kis, rossz a potú támfalat és bizonytalan lépcsőt is. ${ }^{.1-}$

BEFEJEZÉSÜL

Abból a szempontból is jó a két szobor elhelyezése - azon túl, hogy a teret használók felé fordulnak -, hogy a tér kinyilik a Dunára, a pesti oldalon álló Parlament épületére. Ez a tér fổ látványiránya. Az Országgyúlés épületének nagysága miatt (96 méter magas, 268 méter hosszú) olyan, mintha a tér falát képezné. Ezt a hatást erősítik az egyes 作zzletek méretei is (pl. az emeletmahaság, azozó épület mellett jelentős a nagy-

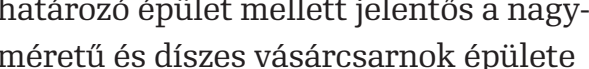
is. Ezekhez képest a Szent Anna templom és plébánia, valamint a szemben alló Erzsébet-rend egykori apácakolos Tora visszafogott, egyszerú épületek nyugodt térfalak: egyszeru epületek, nyok vonják magukra a femplom

\section{A tér két szemközti épülete elött elhe-}

eloulete elott elhe-

egymáshoz:

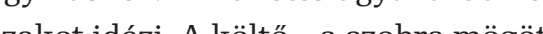

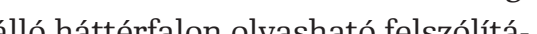
án ess összue jelenkort/Hass, alkoss, gyrapits, s a jaza fényre desil," - Bas, gyaany is eleget tett. Mindketten hozźjany is eleget tett. Mindketten hozzájákozhasson valami tôbbet a népeknek: magasabb kulturat, ertekesebbb, kifejezoóbb nyelvet, illetôleg a szabadság iránt vágy olthatatlan tuzét, a nehéz faladat es a felelösség vállalásának példáját. Látva szobraikat, feltehetjük magunknakk a kérdést: Megfelelünk ezeknek a
kihívásoknak? rultak ahhoz, hogy a magyarság ajajndé

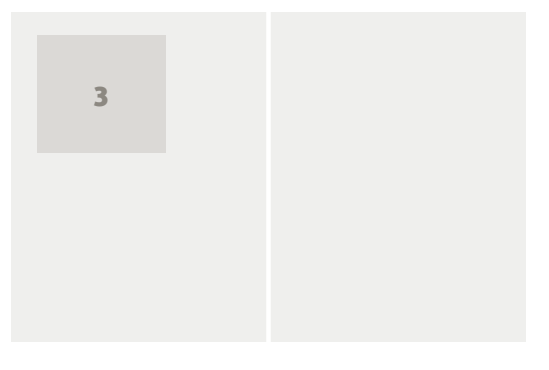

3. kép: A szobor t támfal és a nekifutó

$\begin{array}{ll}\text { kornyezeté. Á ékor lépcsó két külon } \\ \text { alaku üloke ês annak } & \text { téralakitas }\end{array}$

$\begin{array}{ll}\text { kó folytatása (a } & \text { eredménye, ami } \\ \text { szegély) valamint a } & \text { egységet alkot }\end{array}$

15 Telefonos interjú alapján ít sorok, amit a nyilatkozó elfogadott. (2019. szeptember

IN BUDAPES

Víziváros (lit. Water City) is a time(Castle Hill). It is between two popul tourists' areas - the Várnegyed (Cas Quarter) and the downtown of Pest -, situated "in the shade". Batthyány Square is one of the central squares of the district with its former Upper Market place, the parish church and the market-hall that was built at the very beginning of the zoth century. Its peaceful, urban open space state was broken by Kossuth Bridge that was built here after World War II (and stood between 1946-1956), then, the preparatory area of subway constructions occupied most of its territory (1952-1972). No sooner than opening it to the public it has become a bus orminal, an interchang station, and it is being used for the same purpose today too. In the same time here the open space is the oldest remining Ban Baroque square of Budapest that has unfolding view to the Danube.

The prides of the square are the The pride of the sul f the Hur ct the Hungarlan national anthemrative n 1939, and the connmobytery depicting Jesuit priest and poet
Ferenc Faludi (1704-1779) - sculptured by László Szomor. Eponym o the square, Lajos Batthyány - prim minister of the government of the Hungarian Revolution of 1848-1849did not have a sculpture until 2008 . Batthyány, the leader of the first independent Hungarian government was executed. He was buried in secret at night, and not even his name was engraved into his tomb, only his monogram. In Budapest, on site of his execution a sanctuary lamp has been shining in honour of his memory since 1926. The memorial place was the scene of several street demonstrations in 1941, 1943,1979 and 1988. His personality was subject to ambivalent judgement in the years of the socialism, because although he was connected to the revolution, he came from an aristocratic family. However, he was the symbol of indepence Soviet occupation. These reasone went a long way to delay the ens al fis statue by 150 years. The dedication of the 150 yers. The dedication of the piece happened in a velicate situation of domestic politics, The work of art, its entrocty. placement are special due to different placts pects. Durng the Eu devolopment perce of them were excessive developments amassing fountains and other public artworks, including plenty of decorative paving. On the other hand, this particular statue is a fresh exception: moderate, inconspicuous, realising what is just necessary. During the recent years, a certain "past reconstruction" process has been carried out at a number of locations, that included ill-considered "space penetrations", and also a great number of statues came into existence that might have been created centuries ago. Society is divided from an artistic aspect, too. Géza Stremeny's Batthyány statue is a contemporary work of art, that fits into the historical environment in a sensitive way but in the same time it pays attention to the taste of the public as well. By placing the statue and shaping its environment, landscape architect Péter Török created a work of abiding value and temperance. We cherish the hope that their xample becomes exemplary for a greater number of people. 